Article

\title{
Impacts of Tile Drainage on Phosphorus Losses from Edge-of-Field Plots in the Lake Champlain Basin of New York
}

\author{
Laura B. Klaiber ${ }^{1}$ * , Stephen R. Kramer ${ }^{1}$ and Eric O. Young ${ }^{2}$ \\ 1 William H. Miner Agricultural Research Institute, 1034 Miner Farm Rd, Chazy, NY 12921, USA; \\ kramer@whminer.com \\ 2 USDA-ARS, Institute for Environmentally Integrated Dairy Management, 2615 Yellowstone Drive, \\ Marshfield, WI 54449, USA; eric.young@usda.gov \\ * Correspondence: klaiber@whminer.com; Tel.: +1-518-846-7121
}

Received: 31 December 2019; Accepted: 21 January 2020; Published: 23 January 2020

\begin{abstract}
Quantifying the influence of tile drainage on phosphorus $(\mathrm{P})$ transport risk is important where eutrophication is a concern. The objective of this study was to compare P exports from tile-drained (TD) and undrained (UD) edge-of-field plots in northern New York. Four plots (46 by $23 \mathrm{~m}$ ) were established with tile drainage and surface runoff collection during 2012-2013. Grass sod was terminated in fall 2013 and corn (Zea mays L.) for silage was grown in 2014 and 2015. Runoff, total phosphorus (TP), soluble reactive phosphorus (SRP), and total suspended solids (TSS) exports were measured from April 2014 through June 2015. Mean total runoff was 396\% greater for TD, however, surface runoff for TD was reduced by $84 \%$ compared to UD. There was no difference in mean cumulative TP export, while SRP and TSS exports were $55 \%$ and $158 \%$ greater for UD, respectively. A three day rain/snowmelt event resulted in $61 \%$ and $84 \%$ of cumulative SRP exports for TD and UD, respectively, with over $100 \%$ greater TP, SRP and TSS exports for UD. Results indicate that tile drainage substantially reduced surface runoff, TSS and SRP exports while having no impact on TP exports, suggesting tile drains may not increase the overall P export risk.
\end{abstract}

Keywords: tile drainage; surface runoff; phosphorus; edge-of-field; nonpoint source pollution; dairy manure; erosion

\section{Introduction}

Nonpoint source phosphorus (P) loss in agricultural runoff is a major contributor to freshwater eutrophication [1,2] and is the main nonpoint pollutant source in $16 \%$ of impaired lakes and $38 \%$ of impaired streams [3]. In the Lake Champlain Basin and elsewhere, there is a need to better predict the impact of best management practices (BMPs) on P loss risk [4]. For example, USDA's edge-of-field monitoring program is based on small, paired watershed monitoring and designed to quantify the impacts of various BMPs on runoff water quality.

Agricultural subsurface tile drainage (hereafter referred to as 'tile drainage') is a common practice used by farms in humid northern climates to increase crop yield potential. Tile drainage was once considered a BMP due to its ability to reduce surface runoff, erosion and overall P loss in some cases $[5,6]$. Early studies indicated limited movement of $\mathrm{P}$ to tile drains relative to $\mathrm{P}$ loss in surface runoff [7,8]. Baker et al. [9] monitored tile drain flows in Iowa over a three year period and reported low soluble reactive $\mathrm{P}$ (SRP) (less than the detection limit of $0.38 \mu \mathrm{g} \mathrm{L}^{-1}$ ) and total $\mathrm{P}(\mathrm{TP})$ concentrations (7-182 $\mu \mathrm{g} \mathrm{L}^{-1}$, with 6/477 samples $\geq 100 \mu \mathrm{g} \mathrm{L}^{-1}$ ) with correspondingly low TP and SRP loads (0.003 and $0.018 \mathrm{~kg} \mathrm{ha}^{-1}$, respectively). Using replicated plots and simulated rainfall (75 year storm event) in southeastern Minnesota, Zhao et al. [10] showed that $79.2 \%$ to $99.6 \%$ of TP and $75.6 \%$ to $99.8 \%$ 
of SRP across moldboard plow and ridge till treatments was lost via surface runoff (from surface inlets). Research on small catchments in Ontario showed that tile-drained catchments had 90\% less sediment loss and 62\% less total P loss, with no difference in SRP loads compared to undrained catchments [11].

Recent studies have indicated that tile drainage can result in greater P exports than previously assumed; however, the relative proportion of $\mathrm{P}$ lost in surface runoff and tile drainage can be highly site-specific. Field hydrology, soil P saturation, soil type, extent of macropore flow, tillage practices, manure management, storm intensity, cropping patterns, seasonality, and drainage water management can all impact the form and quantity of $P$ exported in surface runoff and tile drain flow [5,10-20]. Smith et al. [18] measured P export in surface runoff and tile drainage over 6-yr in northeastern Indiana and reported that median annual TP export in tile flow ranged from $27 \%$ to $82 \%$ of cumulative $\mathrm{P}$ export (i.e., P loss in surface runoff + tile P loss). Since surface runoff and tile discharge tended to peak simultaneously, the authors suggested that preferential transport of $P$ to tile flow was an important loss mechanism. Madison et al. [21] measured P loss in tile drainage flow and surface runoff at four sites over a five year period in eastern Wisconsin and reported that $66-96 \%$ of total runoff and $17-41 \%$ of cumulative P export was from tile drains. In an eight year study in the upper Big Walnut Creek in central Ohio, King et al. [20] found that $48 \%$ and $40 \%$ of SRP and TP, respectively, was exported via tile flow from the watershed.

While tile-draining poorly drained fields can substantially reduce surface runoff, most tile-drained fields still generate some degree of surface runoff, even those with modest slopes [6]. Since P tends to be concentrated in surface horizons, surface runoff generally has higher P concentrations than tile flow. However, tile drainage typically increases the total amount of water exported from fields and can contribute a substantial fraction of stream flow at the watershed scale [22-24]. King et al. [19] concluded that more studies measuring P loss in both surface runoff and tile drain flow are needed to better understand $\mathrm{P}$ loss partitioning between flow pathways. Additionally, only a few studies have directly compared tiled and untiled sites and the impacts of changing the primary runoff pathway from the surface to the subsurface on the forms and quantity of P lost. As field hydrology and patterns of nutrient loss are significantly impacted by climate and soils, it is important to quantify field hydrology effects on P runoff losses at both landscape and regional scales under controlled but typical agronomic practices. The objective of our study was to compare runoff and P exports between tile-drained (TD) and undrained (UD), small, edge-of-field plots (managed as corn for silage) at a northern New York research farm in the Lake Champlain Basin.

\section{Materials and Methods}

\subsection{Site Description and Plot Establishment}

The experimental site is located within a 1.65 ha field at the Lake Alice Wildlife Management

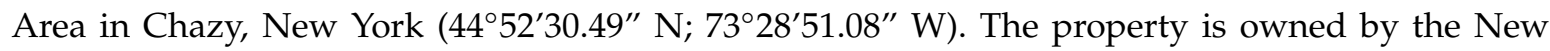
York Department of Environmental Conservation and cropland is managed by the William H. Miner Agricultural Research Institute. Clinton County has an average of $80 \mathrm{~cm}$ year ${ }^{-1}$ of precipitation and a typical growing season of 130 days. Prior to plot establishment, the field was managed as long-term grass hay (Phalaris arundinacea) with no known manure or fertilizer history. In 2012, four experimental plots (46 m long by $23 \mathrm{~m}$ wide) were established parallel to the field slope in a randomized block design. The plots are located on a relatively uniform slope $(5 \%$ downslope and $<1 \%$ transverse slope across all plots) and are mapped as excessively drained outwash (Colosse-Trout River series; sandy-skeletal, mixed, frigid Entic Haplorthods) at the upslope position and very poorly drained (Adjidaumo series; fine, mixed, active, nonacid, frigid Mollic Endoaquepts) at the toeslope [25]. The plots were designed to enable the individual collection of surface and subsurface runoff (Figure 1). Three subsurface tile drainage lines (10 cm diameter) were installed lengthwise in each plot at $7.5 \mathrm{~m}$ spacing and a mean depth of $1 \mathrm{~m}$. The undrained treatment (UD) was established by plugging tile outlets with $100 \mathrm{~mm}$ mechanical plugs (Cherne/Oatey, Cleveland, $\mathrm{OH}$ ), whereas tile-drained plots (TD) remained freely 
drained. Surface runoff was collected by a $30 \mathrm{~cm}$ (i.d.) PVC pipe cut in half and installed in shallow trenches at the toeslope of each plot. Surface and subsurface runoff were routed to manholes at the corner of each plot where flows were sampled and gauged. In May 2013, one soil pit was dug in the center portion of each plot for soil horizon descriptions and sampling. Samples were taken from four sides of each pit from Ap (0-30 cm), Bw (30-51 cm), B/C horizons $(51-91 \mathrm{~cm}+)$ and composited. Samples were sent to the University of Maine's Analytical Laboratory/Maine Soil Testing Service for agronomic testing using the Morgan extractant following Cornell University guidelines.

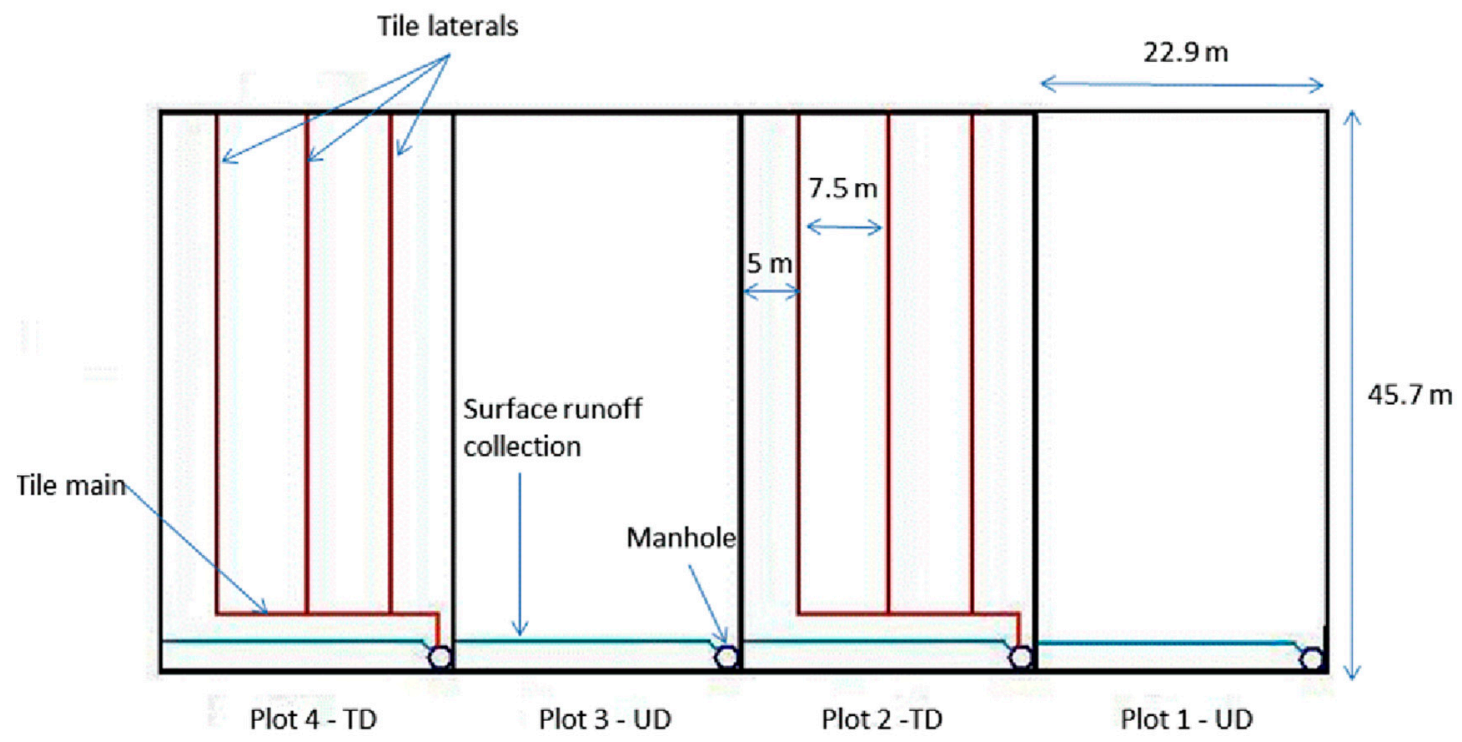

Figure 1. Schematic of tile-drained (TD) and undrained (UD) research plots.

The hay crop was terminated in late September 2013 with glyphosate and liquid dairy manure was broadcast at a rate of $37,400 \mathrm{~L} \mathrm{ha}^{-1}$ (providing $18 \mathrm{~kg} \mathrm{P}_{2} \mathrm{O}_{5} \mathrm{ha}^{-1}$ ), followed by primary tillage with a disk harrow. In May 2014, the field was disk harrowed prior to planting corn (Zea mays L.) for silage in early June 2015 at a rate of 84,000 seeds ha ${ }^{-1}$. At planting, $112 \mathrm{~kg} \mathrm{ha}^{-1}$ of 23:12:18 (NPK) fertilizer was applied through the planter. The field was harvested for silage in October 2014, followed by a broadcast, unincorporated application of liquid dairy manure at a rate of $37,400 \mathrm{~L} \mathrm{ha}^{-1}$ (providing $14 \mathrm{~kg} \mathrm{P}_{2} \mathrm{O}_{5} \mathrm{ha}^{-1}$ ). Corn was planted in late May 2015 following the same procedure as 2014.

\subsection{Runoff Sampling, Flow Measurement and Analytical Methods}

Surface and subsurface runoff flows were measured with $18.9 \mathrm{~L}$ buckets modified with a v-notch weir to enable continuous water flow measurement (Figure 2). Water levels were gauged at $5 \mathrm{~min}$ intervals with pressure transducers (ONSET, Bourne, MA). Cubic regression models were fit to measured flows as a function of water level (mean $R^{2}=0.97 \pm 0.03$ ) and used to estimate runoff. 


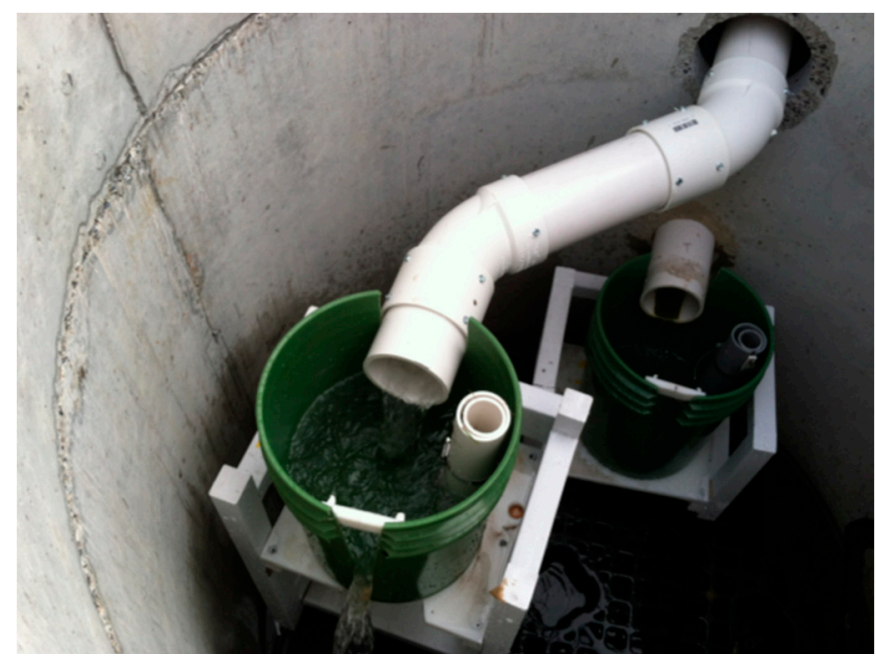

Figure 2. Modified 18.9 L buckets in a concrete manhole gauging tile drainage flows (background) and surface runoff (foreground).

When weather forecasts indicated the potential for large runoff events, ISCO 6712 autosamplers (Teledyne ISCO, Lincoln, NE) were used to take hourly samples for the duration of the event. For all other events, flows were sampled 1-3 times per day and base flows were sampled weekly. Samples from autosamplers were collected within $12 \mathrm{~h}$ following the completion of the $24 \mathrm{~h}$ sampling cycle and immediately transported to the laboratory and refrigerated at $4{ }^{\circ} \mathrm{C}$. Grab samples were taken immediately to the laboratory for refrigeration after collection. Soluble reactive $\mathrm{P}$ was determined within 48 hours of collection after membrane filtration $(<0.45 \mu \mathrm{m})$ by the ascorbic acid-ammonium molybdate colorimetric method [26]. Total $\mathrm{P}$ was determined colorimetrically on unfiltered samples following persulfate digestion [26]. Particulate/unreactive P (PUP) was estimated as the numerical difference between TP and SRP (representing particulate and/or dissolved unreactive P). All runoff samples were analyzed for total suspended solids (TSS) according to Standard Methods 2540 [26].

Loads for each hydrologic pathway by plot were estimated for events captured with autosamplers $(n=7)$ by multiplying hourly SRP, PUP, TP, and TSS concentrations by corresponding hourly flows. For the remaining flows, concentrations were assumed constant from halfway between the previous sample and the subsequent sample for each collection time point and multiplied by the corresponding flows to generate loads [20]. For UD plots, P and TSS exports were based on surface runoff loads only, whereas TD plot-level loads were the sum of tile and surface runoff loads. Flow-weighted mean concentrations (FWM) for the study duration were calculated for SRP, TP, PUP, and TSS by dividing total loads by total runoff. Precipitation data were collected by a weather station (RainWise, Inc., Bar Harbor, ME, USA) located $1.7 \mathrm{~km}$ from the experimental plots, operated by the Network for Environment and Weather Applications. Data reported here include runoff events and base flows measured between 21 April 2014 and 30 June 2015. Runoff events from 9 March to 9 April 2015 could not be measured due to the transition to freezing temperatures during rain and/or snowmelt events, which resulted in ice accumulation in the flow-monitoring equipment and inaccurate flow data.

\subsection{Statistical Analysis}

Plots were arranged in a randomized complete block design. A two-sided Student's $t$-test with blocking was used to determine differences between TD and UD. Response variables included runoff volume, loads, and FWM for SRP, TP, PUP, and TSS. Loading differences among hydrologic pathways (TD-surface runoff, TD-subsurface flow, and UD-surface runoff) were tested with a one-way analysis of variance (ANOVA) with blocking. Means were separated with Tukey's HSD test when there were significant main effects. While some variables were not normally distributed, it was recommended 
that variables not be transformed prior to analysis due to small sample size [27]. As discharge and sample concentration data were not normal, the Spearman correlation was used to test for relationships between discharge, $\mathrm{P}$ forms, and TSS. Significance was declared at a $p$-value $\leq 0.10$, given the low number of replicates and high inherent variability in field hydrology and chemodynamics at this spatial scale. All statistical analyses were performed with JMP PRO 11.2 (SAS Institute Inc., Cary, NC, USA). Unless otherwise specified, all reported runoff, loading rates, soil test $\mathrm{P}$ and FWM concentrations represent the plot-level treatment means (denoted by UD and TD) and the mean of each hydrologic pathway within each treatment (denoted by TD-surface runoff, TD-tile drainage, and UD-surface runoff).

\section{Results and Discussion}

\subsection{Runoff in Tile-Drained and Undrained Plots}

Runoff was consistently greater for TD across all events, ranging from $65 \%$ to $1575 \%$ higher than UD (Table 1). Mean cumulative runoff was $242 \%$ greater for TD, but surface runoff was reduced by $84 \%$ relative to UD ( Table 1; Table 2 ). The vast majority of runoff for TD was via tile drain flow, with only $5 \%$ from surface runoff (Table 2 ). Surface runoff only occurred $6.4 \%$ of the time in TD plots, as compared to $13.5 \%$ for UD. Tile flow occurred in at least one TD plot $54.9 \%$ of the time. These results are supported by other studies showing substantial reductions in or elimination of surface runoff after installation of tile drainage [5,28]. When surface runoff does occur in tile-drained fields, it is typically during high-intensity rain or snowmelt events that result in infiltration excess overland flow [29].

Table 1. Mean runoff, soluble reactive phosphorus (SRP), particulate/unreactive phosphorus (PUP), total phosphorus (TP) and total suspended solids (TSS) export by tile-drained plots (TD) and undrained plots (UD) for all major runoff events and cumulative export for the study duration. Rainfall (mm) for each event is included in parentheses below the event start date.

\begin{tabular}{|c|c|c|c|c|c|c|}
\hline Event Date & Treatment & Runoff (mm) & SRP $\left(\mathrm{g} \mathrm{ha}^{-1}\right)$ & PUP $\left(\mathrm{g} \mathrm{ha}^{-1}\right)$ & $\mathrm{TP}\left(\mathrm{g} \mathrm{ha}^{-1}\right)$ & TSS $\left(\mathrm{kg} \mathrm{ha}^{-1}\right)$ \\
\hline \multirow{2}{*}{$\begin{array}{c}\text { 16 May } 2014 \\
(54.4 \mathrm{~mm})\end{array}$} & TD & $24.4^{\mathrm{a}, \dagger}(5.6)^{\S}$ & $13.63(12.55)$ & $62.23(53.03)$ & 72.95 (65.58) & 42.67 (36.22) \\
\hline & UD & $11.3 \mathrm{~b}(3.2)$ & $1.30(1.06)$ & $14.25(11.66)$ & $15.55(12.72)$ & $113.21(110.36)$ \\
\hline \multirow{2}{*}{$\begin{array}{l}3 \text { June } 2014 \\
(27.9 \mathrm{~mm})\end{array}$} & TD & $10.9(1.3)$ & $0.49(0.34)$ & $15.73(13.44)$ & $16.22(13.77)$ & $14.47(13.20)$ \\
\hline & UD & $4.7(2.6)$ & $0.50(0.33)$ & $5.21(1.51)$ & $5.70(1.18)$ & $9.91(0.65)$ \\
\hline \multirow{2}{*}{$\begin{array}{l}\text { 11 Jun } 2014 \\
(52.3 \mathrm{~mm})\end{array}$} & TD & $19.2^{\mathrm{a}}(1.4)$ & $0.47(0.27)$ & $3.87(16.3)$ & $4.34(1.90)$ & $1.21(1.12)$ \\
\hline & UD & $10.2^{\mathrm{b}}(0.8)$ & $2.11(1.45)$ & $7.40(5.58)$ & $9.48(6.02)$ & $7.21(5.0)$ \\
\hline \multirow{2}{*}{$\begin{array}{l}24 \text { Jun } 2014 \\
(10.9 \mathrm{~mm})\end{array}$} & TD & $2.0^{\mathrm{a}}(0.9)$ & $0.04(0.00)$ & $0.13(0.04)$ & $0.17(0.04)$ & $0.01(0.00)$ \\
\hline & UD & $0.7^{b}(0.7)$ & $0.02(0.01)$ & $0.06(0.05)$ & $0.08(0.06)$ & $0.04(0.03)$ \\
\hline \multirow{2}{*}{$\begin{array}{l}13 \text { August } 2014 \\
(54.1 \mathrm{~mm})\end{array}$} & TD & $6.0^{\mathrm{a}}(1.2)$ & $1.62(1.38)$ & $2.45(2.10)$ & $4.08(3.47)$ & $0.33^{a,+}(0.29)$ \\
\hline & UD & $2.6^{\mathrm{b}}(0.1)$ & $1.73(0.12)$ & $2.49(0.56)$ & $4.22(0.68)$ & $0.84^{\mathrm{b}}(0.18)$ \\
\hline \multirow{2}{*}{$\begin{array}{l}24 \text { December } 2014 \\
(11.4 \mathrm{~mm})\end{array}$} & TD & $50.3(12.2)$ & $51.58(49.03)$ & $14.00(9.81)$ & $65.58(58.84)$ & $1.21(0.97)$ \\
\hline & UD & $30.5(16.8)$ & $110.45(100.21)$ & $27.75(22.88)$ & 138.19 (123.09) & $2.70(1.86)$ \\
\hline \multirow{2}{*}{$\begin{array}{c}31 \text { May } 2015 \\
(30.5 \mathrm{~mm})\end{array}$} & TD & $6.7^{\mathrm{a}}(0.4)$ & $0.86(0.62)$ & $0.90(0.74)$ & $1.76(1.36)$ & $0.18(0.10)$ \\
\hline & UD & $0.4^{\mathrm{b}}(0.2)$ & $0.15(0.04)$ & $0.20(0.09)$ & $0.34(0.13)$ & $0.05(0.05)$ \\
\hline \multirow{2}{*}{$\begin{array}{c}\text { Total } \\
(1042 \mathrm{~mm})\end{array}$} & TD & $559.6^{a}(110.1)$ & $84.19(71.11)$ & $149.40(82.24)$ & $233.59(153.34)$ & $65.45(51.36)$ \\
\hline & UD & $163.8^{\mathrm{b}}(51.1)$ & $130.78(104.26)$ & $98.00(31.83)$ & 228.78 (136.09) & $168.82(101.07)$ \\
\hline
\end{tabular}

${ }^{\dagger}$ Means with different letters are different at $p \leq 0.10 .{ }^{\S}$ Values in parentheses are standard deviation.

Although plots were not hydrologically isolated with a physical barrier, there was no observed mixing of surface runoff among plots across a range of conditions. The $5 \%$ slope promoted surface runoff flow down the length of the plots to the collection point and the minimal transverse slope between plots likely contributed to the lack of visible lateral surface water movement. With respect to subsurface water, some degree of subsurface lateral flow mixing between treatments cannot be ruled out, however, a hydraulic gradient encouraging lateral seepage from UD to TD plots would likely only 
have developed late in the course of a runoff event (as the water table receded and tile drainage flows returned to baseflow conditions).

Table 2. Mean runoff, soluble reactive phosphorus (SRP), particulate/unreactive phosphorus (PUP), total phosphorus (TP) and total suspended solids (TSS) export by each runoff pathway in tile-drained plots (TD) and undrained plots (UD) for all major runoff events and cumulative export for the study duration. Rainfall (mm) for each event is included in parentheses below the event start date.

\begin{tabular}{|c|c|c|c|c|c|c|}
\hline Event Date & Treatment & Runoff (mm) & SRP (g ha-1) & PUP (g ha-1) & TP $\left(\mathrm{g} \mathrm{ha}^{-1}\right)$ & TSS $\left(\mathrm{kg} \mathrm{ha}^{-1}\right)$ \\
\hline \multirow{3}{*}{$\begin{array}{l}\text { 16 May } 2014 \\
(54.4 \mathrm{~mm})\end{array}$} & UD-surface & $11.3(3.2)^{\S}$ & $1.30(1.06)$ & $14.25(11.66)$ & 15.55 (14.46) & $113.21(111.80)$ \\
\hline & TD-surface & $8.9(8.5)$ & $13.12(12.56)$ & $47.18(46.18)$ & $60.31(58.73)$ & $36.04(35.87)$ \\
\hline & TD-tile & $15.4(2.8)$ & $0.50(0.01)$ & $15.06(6.86)$ & $12.64(6.85)$ & $6.63(0.35)$ \\
\hline \multirow{3}{*}{$\begin{array}{l}\text { 3 Jun } 2014 \\
(27.9 \mathrm{~mm})\end{array}$} & UD-surface & $4.7(2.6)$ & $0.50(0.33)$ & $5.21(1.51)$ & $5.70(1.18)$ & $9.91(0.65)$ \\
\hline & TD-surface & $2.8(2.2)$ & $0.36(0.32)$ & $10.87(9.74)$ & $11.23(10.07)$ & $13.63(12.93)$ \\
\hline & TD-tile & $8.1(0.9)$ & $0.13(0.02)$ & $4.86(3.69)$ & $4.99(3.71)$ & $0.84(0.26)$ \\
\hline \multirow{3}{*}{$\begin{array}{c}11 \text { Jun } 2014 \\
(52.3 \mathrm{~mm})\end{array}$} & UD-surface & $10.2^{\mathrm{ab},+}(0.8)$ & $1.87(1.45)$ & $6.54(4.58)$ & $8.41(6.02)$ & $2.32(1.55)$ \\
\hline & TD-surface & $1.3^{\mathrm{b}}(1.3)$ & $0.13(0.14)$ & $0.94(0.93)$ & $1.08(1.08)$ & $0.34(0.34)$ \\
\hline & TD-tile & $18.0^{\mathrm{a}}(2.6)$ & $0.39(0.13)$ & $2.88(0.68)$ & $3.27(0.81)$ & $0.29(0.18)$ \\
\hline \multirow{3}{*}{$\begin{array}{l}24 \text { Jun } 2014 \\
(10.9 \mathrm{~mm})\end{array}$} & UD-surface & $0.7(0.7)$ & $0.02(0.01)$ & $0.06(0.05)$ & $0.08(0.06)$ & $0.04(0.03)$ \\
\hline & TD-surface & $0.0(0.0)$ & $0.01(0.01)$ & $0.06(0.04)$ & $0.07(0.06)$ & $0.00(0.00)$ \\
\hline & TD-tile & $2.0(0.9)$ & $0.03(0.01)$ & $0.07(0.01)$ & $0.10(0.02)$ & $0.01(0.01)$ \\
\hline \multirow{3}{*}{$\begin{array}{l}13 \text { August } 2014 \\
(54.1 \mathrm{~mm})\end{array}$} & UD-surface & $2.6(0.1)$ & $1.73(0.12)$ & $2.49(0.56)$ & $4.22(0.68)$ & $0.84^{\mathrm{a},+}(0.18)$ \\
\hline & TD-surface & $1.4(1.2)$ & $1.27(1.23)$ & $1.17(1.14)$ & $2.44(2.38)$ & $0.17^{\mathrm{b}}(0.16)$ \\
\hline & TD-tile & $4.6(0.0)$ & $0.35(0.14)$ & $1.28(0.95)$ & $1.63(1.10)$ & $0.16^{\mathrm{b}}(0.13)$ \\
\hline \multirow{3}{*}{$\begin{array}{l}24 \text { December } 2014 \\
\quad(11.4 \mathrm{~mm})\end{array}$} & UD-surface & $30.5^{\mathrm{ab}}(16.8)$ & $110.45(100.21)$ & $27.75(22.88)$ & $138.19(123.09)$ & $2.70(1.86)$ \\
\hline & TD-surface & $4.4^{\mathrm{b}}(4.1)$ & $11.28(9.42)$ & $2.08(1.80)$ & 13.36 (11.22) & $0.21(0.19)$ \\
\hline & TD-tile & $45.9^{a}(8.1)$ & $40.30(39.61)$ & $11.92(8.01)$ & $52.22(47.61)$ & $1.00(0.78)$ \\
\hline \multirow{3}{*}{$\begin{array}{l}31 \text { May } 2015 \\
(30.5 \mathrm{~mm})\end{array}$} & UD-surface & $0.4^{\mathrm{b}}(0.4)$ & $0.15(0.04)$ & $0.20(0.09)$ & $0.34(0.13)$ & $0.05(0.05)$ \\
\hline & TD-surface & $0.5^{\mathrm{b}}(0.4)$ & $0.56(0.54)$ & $0.25(0.23)$ & $0.81(0.77)$ & $0.02(0.02)$ \\
\hline & TD-tile & $6.2^{\mathrm{a}}(0.2)$ & $0.30(0.08)$ & $0.66(0.51)$ & $0.96(0.59)$ & $0.16(0.08)$ \\
\hline \multirow{3}{*}{$\begin{array}{c}\text { Total } \\
(1042 \mathrm{~mm})\end{array}$} & UD-surface & $163.8^{\mathrm{ab}}(51.1)$ & $130.79(104.26)$ & $100.10(31.83)$ & $230.87(136.09)$ & $162.29(101.07)$ \\
\hline & TD-surface & $25.8^{\mathrm{a}}(22.9)$ & $34.01(30.61)$ & $68.54(64.92)$ & $102.52(95.53)$ & $50.99(50.00)$ \\
\hline & TD-tile & $533.8^{\mathrm{b}}(133.0)$ & 50.17 (40.49) & 81.15 (17.32) & $131.35(57.81)$ & $14.46(1.36)$ \\
\hline
\end{tabular}

${ }^{\dagger}$ Means with different letters are different at $p \leq 0.10 .{ }^{\S}$ Values in parentheses are standard deviation.

Thirty-five percent of the total surface runoff for TD $(9 \mathrm{~mm})$ occurred during an event that began on 16 May 2014. The event was characterized by the highest rainfall total $(54 \mathrm{~mm})$ and the second highest hourly rainfall rate $\left(15 \mathrm{~mm} \mathrm{~h}^{-1}\right)$ (Table 2, Figure 3a). Surface runoff for TD and UD responded similarly in time and magnitude, with peak discharge occurring simultaneously with peak rainfall. Tile discharge for TD peaked approximately $2 \mathrm{~h}$ after surface runoff in both TD plots. Smith et al. [18] reported that surface and tile discharges in four monitored fields often peaked simultaneously, indicating that preferential flow pathways were responsible for a significant proportion of tile flow. Although peak tile discharge did not occur simultaneously with surface discharge, the relatively rapid response of tile flow likely indicates preferential flow pathways were active. The rainfall characteristics of the 3 June 2014 event were similar to the 16 May 2014 event (brief, high-intensity rainfall), but with lower antecedent moisture conditions (36\% lower tile discharge in TD). In this case, the influence of preferential flow pathways was clear, as peak tile and surface discharges occurred simultaneously (Figure 3b). The nearly simultaneous response of surface runoff in both treatments to the onset of rain in these events indicates infiltration excess runoff [30]. For high-intensity rain events such as these, tile drainage systems may have a minimal impact on reducing surface runoff, as soil properties play a greater role in determining infiltration rates. This is reflected in our data as the surface runoff volumes were similar between treatments during these two events, despite the activity of preferential flow pathways in TD. In contrast, the 11 June 2014 (Figure 3c) and 24 December 2014 (Figure 3D) events 
occurred over a period of days rather than hours due to extended rain and rain/snowmelt, resulting in $87 \%$ and $86 \%$ reductions, respectively, in surface runoff for TD.

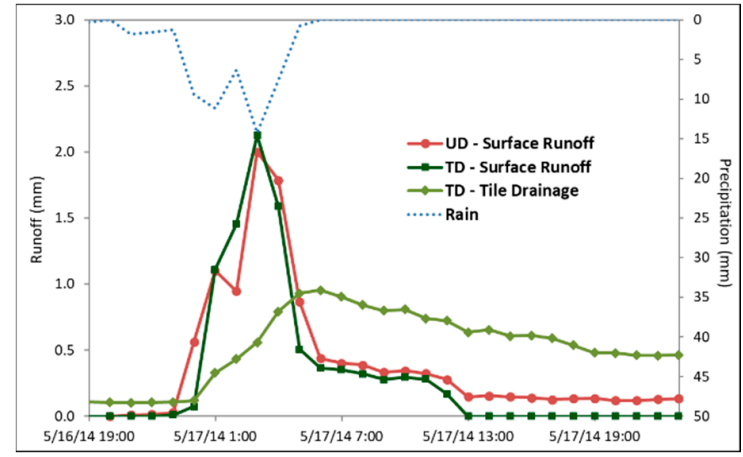

(a)

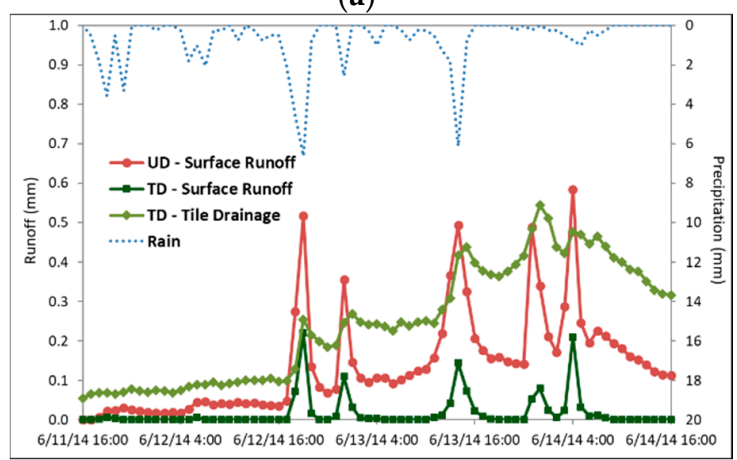

(c)

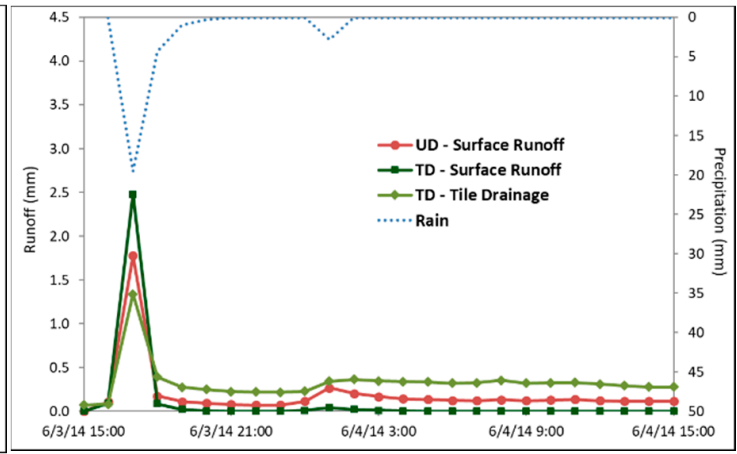

(b)

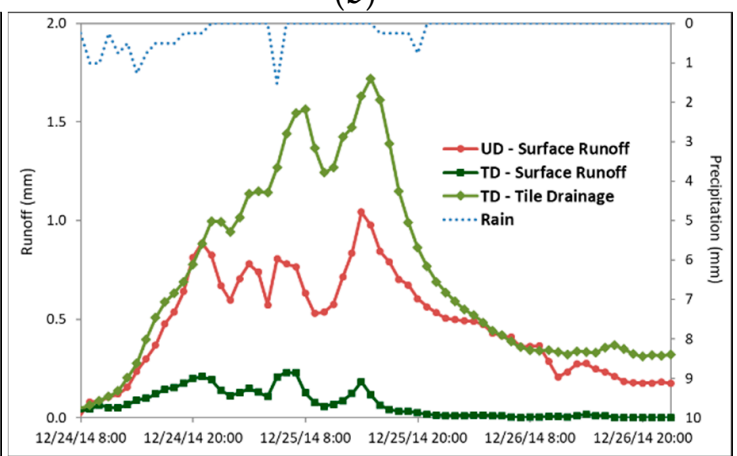

(d)

Figure 3. Precipitation and mean runoff by hydrologic pathway for the tile-drained (TD) and undrained (UD) plots for four runoff events beginning on (a) 16 May 2014; (b) 3 June 2014; (c) 11 June 2014; and (d) 24 December 2014 .

The 24 December 2014 event highlights the quantitative importance of nongrowing season (NGS) runoff, contributing $9 \%(50.3 \mathrm{~mm})$ and $18 \%(30.5 \mathrm{~mm})$ of the cumulative runoff from TD and UD, respectively, as well as $17 \%(4.4 \mathrm{~mm})$ of cumulative surface runoff for TD. In northern climates, the majority of annual precipitation typically occurs during the NGS [9,31], generating more runoff compared with warmer months with higher evapotranspiration rates. Tan et al. [32] reported that tile drain flow during the NGS accounted for $64 \%$ of annual drainage. Research has also indicated the potential for large volumes of surface runoff from snowmelt events [33,34]. The 24 December 2014 event demonstrated that the enhanced drainage capacity of tile-drained fields has the potential to substantially reduce surface runoff during snowmelt events. With no frost layer impeding the movement of surface water through the soil profile, the tiles in TD responded immediately to snowmelt, resulting in an $86 \%$ reduction in surface runoff relative to UD.

There was no tile flow during the 31 day period in late winter when continuous monitoring was not possible (bucket gauges remained empty), likely due to frozen soil layers preventing the transport of surface water to tile drains. However, during this period, the snowpack was completely lost in early March 2015, resulting in considerable surface runoff. Manual flow measurements taken during this event were greater than any others recorded $\left(5.5 \mathrm{~mm} \mathrm{~h}^{-1}\right)$, indicating that this was a high risk period for erosion and $\mathrm{P}$ transport in surface runoff.

\subsection{Export of Phosphorus and Total Suspended Solids}

There was no difference in cumulative TP export between TD (233.6 $\left.\mathrm{g} \mathrm{ha}^{-1}\right)$ and UD (228.8 $\mathrm{g} \mathrm{ha}^{-1}$; Table 1). Tile drainage accounted for $56 \%$ of TP exports from TD (Table 2). The losses from UD and TD reflect 13.5 months of monitoring data and are relatively low in comparison to the range of annual 
TP losses from tile drains alone (0.4-1.6 $\mathrm{kg} \mathrm{ha}^{-1}$ year $\left.^{-1}\right)$, as reported by King et al [19]. A significant runoff event that was not measured in March 2015 (when a majority of spring snowmelt occurred) may have also contributed to the relatively low TP exports in our study. Additionally, plots had low Morgan-extractable P (hereafter referred to as soil test $\mathrm{P}$; STP) in Ap horizons (TD $=0.78 \pm 0.01 \mathrm{mg} \mathrm{kg}^{-1}$; $\mathrm{UD}=0.90 \pm 0.30 \mathrm{mg} \mathrm{kg}^{-1}$ ) and subsoil (TD $=0.94 \pm 0.04 \mathrm{mg} \mathrm{kg}^{-1} ; \mathrm{UD}=0.80 \pm 0.10 \mathrm{mg} \mathrm{kg}^{-1}$ ). Several studies report strong relationships between molybdate-reactive $\mathrm{P}$ release (assumed to be mainly orthophosphate-P) and surface runoff, and subsurface drainage and STP measured by various procedures [35-39].

The range of STP concentrations at our site is considered low by Cornell University guidelines and implies a low soil solution P status and a need for additional P to meet crop needs. While UD had 158\% greater mean cumulative TSS export than TD, considering the limited relationship between TP and TSS concentrations in surface runoff $\left(r_{S}=0.50, P<0.001\right)$, manure application may have been a more important source of runoff P. Manure was broadcast in the late fall of 2013 and 2014 and the majority of SRP (TD = 77\%; UD = 85\%) and TP losses (TD = 59\%; UD =67\%) in our study occurred during two events in the NGS. Despite similar TP losses, SRP export for UD (130.8 $\left.\mathrm{g} \mathrm{ha}^{-1}\right)$ was 55\% greater than TD (84.2 $\left.\mathrm{g} \mathrm{ha}^{-1}\right)$, representing $57 \%$ and $36 \%$ of cumulative TP exports for UD and TD, respectively. Although particulate $\mathrm{P}$ loss in surface runoff is often a large component of P export [15,40], results from our study indicate that a high proportion of SRP can also be lost in surface runoff following manure application.

The combined influences of weather and manure management on P transport were demonstrated by the 24 December 2014 event (Figure 4). Mean TP exports from TD and UD were $65.6 \mathrm{~g} \mathrm{ha}^{-1}$ and $138.2 \mathrm{~g} \mathrm{ha}^{-1}$, respectively, for this event, and responsible for $28 \%$ of cumulative TP exports from TD and $60 \%$ of TP exports from UD. Jamieson et al., [33] observed similar losses during a four day snowmelt event for a tile-drained field in southern Quebec that resulted in $164.8 \mathrm{~mm}$ of total runoff (surface + tile drain). They reported TP exports of $166.4 \mathrm{~g} \mathrm{ha}^{-1}$ for surface runoff and $98.2 \mathrm{~g} \mathrm{ha}^{-1}$ for tile flow, with the surface losses accounting for $96.7 \%$ of annual TP export (cumulative tile TP exports not reported). In our study, SRP represented 79\% and $80 \%$ of mean TP exports for UD and TD, respectively, during the 24 December 2014 snowmelt event.

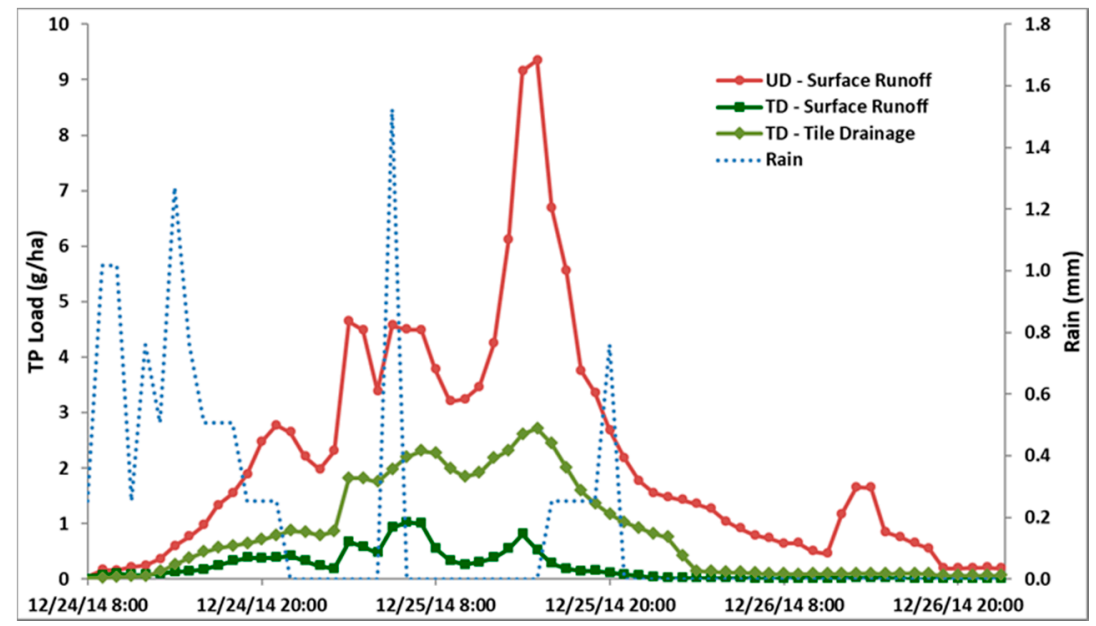

Figure 4. Total phosphorus (TP) loading by hydrologic pathway from tile-drained (TD) and undrained (UD) plots during the 24 December 2014 runoff event.

The influence of season on $\mathrm{P}$ speciation in surface runoff and tile flow are inconsistent in the literature, with some studies reporting increased particulate $\mathrm{P}$ in the winter and others reporting that dissolved P is more prevalent [23,41,42]. The high fraction of SRP exports for the 24 December 2014 event is likely related to a manure application that occurred four weeks prior to the event. Manure was broadcast with no incorporation, and post-application mean temperatures were at or below freezing. 
Post-application precipitation occurred as snow and sleet prior to $1.73 \mathrm{~cm}$ of cumulative rainfall on 23 December 2014 and 24 December 2014. Snowmelt began on 24 December 2014, the first of three consecutive days in which temperatures remained above $40^{\circ} \mathrm{F}$. We hypothesize that the manure application provided a labile P source near the soil surface that was vulnerable to surface runoff loss during snowmelt. The fact that manure was not incorporated may have exacerbated P leaching to tiles, since tillage both mixes manure into the soil, encouraging P sorption, and disrupts macropores [13,15]. The combination of unincorporated manure and snow accumulation with subsequent melting and rainfall may have provided ideal conditions for $\mathrm{P}$ mobilization in surface runoff and leaching to tile drains. As previously noted, the enhanced drainage capacity of TD resulted in substantial reductions in surface runoff relative to UD for this event. Despite much greater total runoff from TD, TP and SRP exports in surface runoff were both 53\% less than UD for this event (Table 1 ). While others have demonstrated that surface-applied P can be directly transported to tile drains via preferential flow pathways $[13,14]$, the opportunity remains in tile-drained systems to increase the percentage of applied $P$ that can be sorbed as shallow subsurface flow interacts with the soil profile. In contrast, surface runoff has minimal opportunity for P sorption once mobilized. This may be particularly important in humid northern regions where surface runoff from snowmelt can be considerable.

Very high P concentrations were also measured in surface runoff during snowmelt in March 2015 (no tile flow). Grab samples taken from UD on 11 March 2015 had TP and SRP concentrations of 2.31 and $2.13 \mathrm{mg} \mathrm{L}^{-1}$, respectively. Maximum TP and SRP concentrations for TD were 2.63 and $2.46 \mathrm{mg} \mathrm{L}^{-1}$, respectively. Although the lack of continuous flow data throughout the event precluded load estimates, these elevated P concentrations and associated high instantaneous flow measurements support the idea that snowmelt can have a disproportionate contribution to P losses in runoff, particularly when fall-applied manure is not incorporated and vulnerable to runoff.

The 16 May 2014 runoff event resulted in substantial TSS and P exports. A total of $54 \mathrm{~mm}$ of rain occurred in $9 \mathrm{~h}$, generating the highest rainfall rates and largest TSS losses from a single event (Figure 5). The event occurred prior to planting, and therefore the soil had no protection from raindrop impact or root system to stabilize the soil. This event was responsible for $65 \%$ and $71 \%$ of cumulative TSS exports from TD and UD, respectively, with losses primarily occurring over a $2 \mathrm{~h}$ period with an average rainfall rate of $11 \mathrm{~mm} \mathrm{~h}^{-1}$. Exports of TSS in surface runoff were $165 \%$ greater for UD, with $214 \%$ more TSS exports from UD surface runoff compared to TD surface runoff (Table 2). While TSS exports were much greater from surface runoff in both treatments, $46 \%$ of cumulative subsurface TSS exports from TD $\left(6.6 \mathrm{~kg} \mathrm{ha}^{-1}\right)$ occurred during this event.

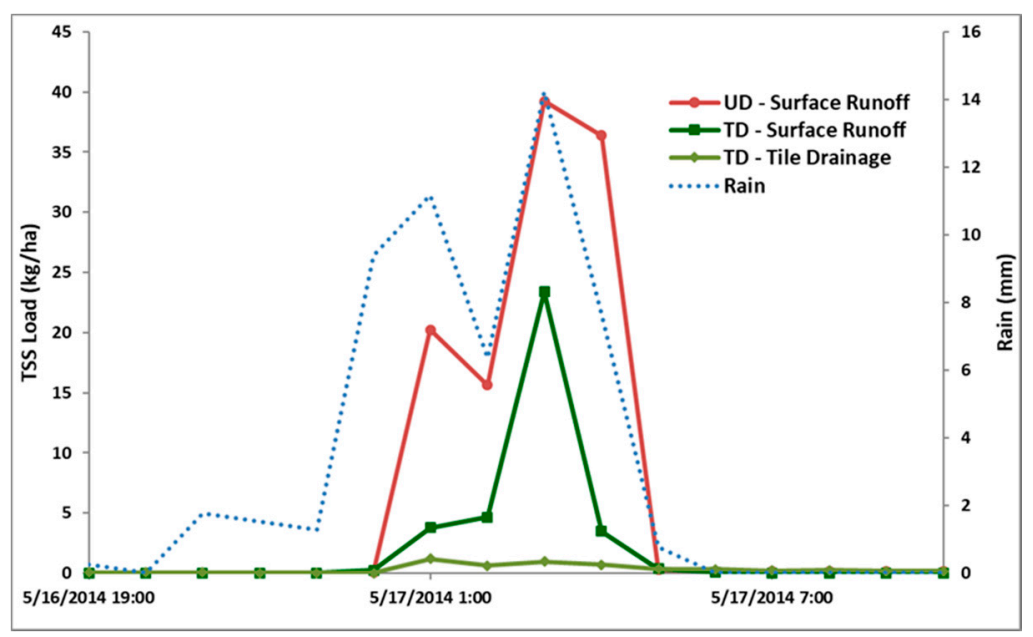

Figure 5. Total suspended solids (TSS) loading by hydrologic pathway from tile-drained (TD) and undrained (UD) plots during the 16 May 2014 runoff event. 
Despite the greater TSS loss from UD, mean TP export was approximately $368 \%$ greater for TD (73.0 $\mathrm{g} \mathrm{ha}^{-1}$ vs. $15.6 \mathrm{~g} \mathrm{ha}^{-1}$ for UD), $65 \%$ of which was exported by surface runoff. Since STP was similar among plots, it is not likely that variation in soil $\mathrm{P}$ contributed substantially to differences in $\mathrm{P}$ loading. However, it is possible that the timing of transport within plots relative to sampling may have contributed to differences in surface runoff $\mathrm{P}$ concentrations. The difference in TP export was largely driven by a surface runoff sample taken from one of the TD plots, and it is possible that the sample was not representative of the water that was lost during the hour-long period that it represents, given the difference relative to all other samples. The sample was taken during the peak of the hydrograph and its concentration was $340 \%$ higher than the next highest sample from any of the plots. This combination of peak flow and elevated concentration resulted in a 50\% increase in the mean P load from TD than would have otherwise been measured if the next highest concentration was used to calculate the hourly load.

The P exports from the 16 May 2014 and 24 December 2014 events demonstrate that a large fraction of annual P loss can occur in a short period of time. For TD, approximately $78 \%, 66 \%$, and $89 \%$ of mean SRP, TP, and TSS exports, respectively, occurred during four runoff events. The percentages were similar for UD, with $86 \%, 70 \%$, and 75\% of SRP, TP, and TSS losses, respectively, occurring during the same events. Sharpley et al. [43] observed a similar pattern during ten years of monitoring a 39.5 ha sub-watershed of Mahantango Creek in south-central Pennsylvania. From 1997 to 2006, storm flow only accounted for $32 \%$ of the watershed discharge, but was responsible for $65 \%$ and $80 \%$ of DP and TP exports, respectively. Additionally, $23 \%$ of TP exported during their study period was from just two storms with a 10 year return period. Although it can be difficult to predict when $\mathrm{P}$ losses will occur, year-round edge-of-field monitoring is essential to better understanding seasonal P exports and developing BMPs to target these critical periods.

\subsection{Flow-Weighted Mean Concentrations}

Flow-weighted mean (FWM) TSS and P concentrations over the study duration were much higher in UD than TD. These differences were driven by surface runoff concentrations that were consistently greater than those in tile flow, regardless of treatment. However, as surface runoff was only $5 \%$ of total flow in TD, the elevated concentrations were mitigated by the low FWM concentrations in tile runoff. The FWM SRP, PUP, TP, and TSS concentrations for the UD-surface runoff were 789\%, 307\%, 464\%, and $3200 \%$ greater than respective FWM concentrations for TD-tile drainage (Table 3). These large differences indicate that surface runoff was capable of mobilizing larger quantities of sediment and P compared to tile drains in our study. Although the FWM concentrations of SRP and TP in surface runoff for TD were $65 \%$ and $182 \%$ greater than those in UD, this is likely because surface flows only occurred in TD during the most severe storms/runoff events.

Table 3. Flow-weighted mean concentrations of soluble reactive phosphorus (SRP), particulate/ unreactive phosphorus (PUP), total phosphorus (TP), and total suspended solids (TSS) by runoff pathway in tile-drained (TD) and undrained (UD) plots.

\begin{tabular}{|c|c|c|c|c|c|}
\hline Treatment & Pathway & $\operatorname{SRP}\left(\mu \mathrm{g} \mathrm{L}^{-1}\right)$ & PUP $\left(\mu \mathrm{g} \mathrm{L}^{-1}\right)$ & $\mathrm{TP}\left(\mu \mathrm{g} \mathrm{L}^{-1}\right)$ & $\operatorname{TSS}\left(\mathrm{mg} \mathrm{L}^{-1}\right)$ \\
\hline UD & surface & 80 & 61 & 141 & 99 \\
\hline TD & surface & 132 & 265 & 397 & 197 \\
\hline TD & tile & 9 & 15 & 25 & 3 \\
\hline
\end{tabular}

Surface water FWM TP concentrations for both treatments were well above $20 \mu \mathrm{g} \mathrm{L}-1$, a commonly cited threshold for the eutrophication of freshwater systems [44], whereas the FWM TP concentration for tile drain flow was only slightly above, at $25 \mu \mathrm{g} \mathrm{L}-1$ (Table 3). Additionally, USEPA recommends that total dissolved $\mathrm{P}$ (TDP) concentrations in waters draining to streams and rivers be $\leq 100 \mu \mathrm{g} \mathrm{L}^{-1}$. While FWM TP (which includes particulate P, not just TDP) for tile flow was clearly well below this, FWM TP in surface runoff for TD and UD were 397 and $141 \mu \mathrm{g} \mathrm{L}^{-1}$, respectively. In general, FWM 
TP and SRP concentrations for tile flow measured in our study were lower than those reported in the literature. For example, King et al. [19] found a higher range of FWM TP concentrations for tiles, with a mean of $150 \mu \mathrm{g} \mathrm{L}^{-1}$. As previously mentioned, the lower tile flow P loss in our study could be partially attributed to its low STP status and therefore lower P leaching risk to tile flow in general, compared to soils with higher STP and labile P concentrations [12].

\subsection{Study Limitations}

As alluded to, while the lack of complete hydrologic isolation between plots may have confounded treatment runoff responses, we suspect that UD subsurface flow contributing to subsurface flow in TD treatments would have mainly occurred after peak flows, during the return to base flows; this is also when TSS and P tend to decrease relative to peak flow. At the same time, if UD water table elevations were lowered as an artifact of TD plots, some reduction in surface runoff and P loss from UD would have also occurred, given the importance of surface runoff as the main P loss pathway in our study. While some degree of lateral subsurface flow mixing may have occurred along TD-UD plot boundaries, we suspect the overall impact on plot-level runoff and P transport was likely small compared to the main effect of tile drainage/simulated natural drainage and soil property variation along the main slope.

The inability to monitor all runoff events was also a limitation in this study. The large snowmelt event in March 2015 would likely have contributed a substantial proportion of the annual P load. However, as this event occurred when a soil frost layer prevented subsurface drainage, the loading would likely have been evenly distributed across all plots and therefore not have further informed the primary research question.

\subsection{Water Quality Implications}

Although there was no difference in TP exports between treatments, mean SRP and TSS exports were $36 \%$ and $61 \%$ lower for TD. Our results contrast with the findings of Eastman et al. [16] who reported greater cumulative TP export for a tile-drained field relative to a naturally drained field in the Pike River Watershed in southern Quebec. The average TP export over 2004 and 2005 was $2.9 \mathrm{~kg} \mathrm{ha}^{-1}$ year $^{-1}$ for the tiled field (66\% from tile flow) and $0.9 \mathrm{~kg} \mathrm{ha}^{-1} \mathrm{year}^{-1}$ for the naturally drained field (surface runoff only). As mentioned, the lower TP export in our study, as compared to Eastman et al. [16] and others [6,19], may be partially due to the low STP status of our plots. In general, there is a higher risk of $\mathrm{P}$ export from tile drains as STP levels increase, particularly above agronomic optimum levels $[35,37,45]$. Preventing P accumulation and excessive soil P concentrations is critical, since considerable time is required to draw P back down to optimum levels [46].

In addition to the quantity of $\mathrm{P}$ inputs, the timing of $\mathrm{P}$ application in relation to runoff potential is also important. The impact of NGS manure applications and snowmelt on P loss risk in surface runoff and tile drainage flow was clearly shown in our study. Coelho et al. [11] reported that $80 \%$ of annual TDP export was from snowmelt, while Jamieson et al. [33] showed that 97\% of annual TP was lost during a four day snowmelt. Gentry et al. [47] reported that a rain/snowmelt event following a late fall broadcast application of P fertilizer resulted in $40 \%$ of the annual TP load to a stream in Illinois. Using a calibrated simulation model (SurPhos), Vadas et al. [48] concluded that winter manure application increased TP export in surface runoff by 2.5 to 3.6 times relative to non-winter application for fields in Wisconsin. Easton et al. [49] reviewed several high-resolution models designed to forecast soil saturation/runoff risk for several different states, with the idea of improving manure/fertilizer application timing to minimize runoff potential. In New York, Dahlke et al. [50] developed and validated the New York Hydrologically Sensitive Area Tool to predict fractional saturated zones at the field scale, using a variable source area hydrology model/water balance model driven by $24 \mathrm{~h}$ and $48 \mathrm{~h}$ NOAA rainfall and temperature forecasts. Tools such as this, along with next generation $\mathrm{P}$ indices calibrated to edge-of-field runoff $\mathrm{P}$ losses that can account for other key factors such as tile drains, cover crops, and manure management [51,52], show promise for better managing future P transport risk. 
The high P concentrations and exports associated with snowmelt demonstrate the importance of continuous, year-round monitoring. The ability to measure $\mathrm{P}$ losses during periods of both maximum flow and $\mathrm{P}$ concentration is important for characterizing incidental $\mathrm{P}$ transfer dynamics, cumulative $\mathrm{P}$ export and assessing seasonal $\mathrm{P}$ loss risk with respect to water quality. The difficulty of maintaining an ice-free environment with sampling equipment during periods of fluctuating freezing/thawing temperatures needs special consideration. Specific monitoring techniques will depend on geography, objectives, cost, and logistical constraints.

\section{Conclusions}

The results of this study indicate that the installation of tile drainage into agricultural fields may not necessarily result in additional $\mathrm{P}$ losses relative to an undrained field under similar management. The enhanced subsurface drainage capacity of the TD plots resulted in a reduction in the frequency and magnitude of surface runoff, which could have a positive impact on water quality where erosion is a concern, surface soils are P-enriched, or runoff closely follows surface-applied nutrients. The absence of a treatment effect on TP loss is likely due to the low labile soil $\mathrm{P}$ at the site and, therefore, the low $\mathrm{P}$ content in eroded sediments. Although TP losses were similar between treatments, SRP losses were substantially lower from TD plots, which could have positive water quality implications for Lake Champlain and other impaired water bodies due to a reduction in bioavailable P transport. Seasonal differences in $\mathrm{P}$ forms and mobility were demonstrated, and additional years and improved monitoring during the non-growing season will provide additional information on the hydrology and $\mathrm{P}$ dynamics of the experimental site in order to develop more robust conclusions.

Author Contributions: Conceptualization, E.O.Y.; Data curation, L.B.K.; Formal analysis, L.B.K. and E.O.Y.; Funding acquisition, E.O.Y.; Investigation, L.B.K. and S.R.K.; Methodology, L.B.K., S.R.K. and E.O.Y.; Project administration, S.R.K.; Writing—original draft, L.B.K. and E.O.Y.; Writing—review and editing, L.B.K., S.R.K. and E.O.Y. All authors have read and agreed to the published version of the manuscript.

Funding: This research was funded in part by the Northern New York Agricultural Development Program.

Acknowledgments: We thank the New York State Department of Environmental Conservation for their cooperation and use of the land to conduct this study.

Conflicts of Interest: The authors declare no conflict of interest. The funders had no role in the design of the study; in the collection, analyses, or interpretation of data; in the writing of the manuscript, or in the decision to publish the results.

\section{References}

1. Sharpley, A.N.; McDowell, R.W.; Kleinman, P.J.A. Phosphorus loss from land to water: Integrating agricultural and environmental management. Plant Soil 2001, 237, 287-307. [CrossRef]

2. Foy, R.H. The return of the phosphorus paradigm; agricultural phosphorus and eutrophication. In Phosphorus: Agriculture and the Environment; Sims, J.T., Sharpley, A.N., Eds.; ASA-CSA-SSSA: Madison, WI, USA, 2005; pp. 1021-1068.

3. USEPA. National Water Quality Inventory: Report to Congress. 2004 Reporting Cycle; United States Environmental Protection Agency Office of Water: Washington, DC, USA, 2009; EPA 841-R-08-001.

4. Sharpley, A.N.; Foy, B.; Withers, P. Practical and innovative measures for the control of agricultural phosphorus losses to water: An overview. J. Environ. Qual. 2000, 29, 1-9. [CrossRef]

5. Skaggs, R.W.; Brevé, M.A.; Gilliam, J.W. Hydrologic and water quality impacts of agricultural drainage. Crit. Rev. Environ. Sci. Tec. 1994, 24, 1-32. [CrossRef]

6. Gilliam, J.W.; Baker, J.L.; Reddy, K.R. Water quality effects of drainage in humid regions. In Agricultural Drainage; Skaggs, R.W., van Schilfgaarde, J., Eds.; American Society of Agronomy: Madison, WI, USA, 1999; pp. 801-830.

7. Benoit, G.R. Effect of agricultural management of wet sloping soil on nitrate and phosphorus in surface and subsurface water. Water Resour. Res. 1973, 9, 1296-1303. [CrossRef]

8. Hanway, J.J.; Laflen, J.M. Plant nutrient losses from tile-outlet terraces. J. Environ. Qual. 1974, 3, 351-356. [CrossRef] 
9. Baker, J.L.; Campbell, K.L.; Johnson, H.P.; Hanway, J.J. Nitrate, phosphorus, and sulfate in subsurface drainage water. J. Environ. Qual. 1975, 4, 406-412. [CrossRef]

10. Zhao, S.L.; Gupta, S.C.; Huggins, D.R.; Moncrief, J.F. Tillage and nutrient source effects on surface and subsurface water quality at corn planting. J. Environ. Qual. 2001, 30, 998-1008. [CrossRef]

11. Coelho, B.B.; Murray, R.; Lapen, D.; Topp, E.; Bruin, A. Phosphorus and sediment loading to surface waters from liquid swine manure application under different drainage and tillage practices. Agric. Water Manag. 2012, 104, 51-61. [CrossRef]

12. Sims, J.T.; Simard, R.R.; Joern, B.C. Phosphorus loss in agricultural drainage: Historical perspective and current research. J. Environ. Qual. 1998, 27, 277-293. [CrossRef]

13. Geohring, L.D.; McHugh, O.V.; Walter, M.T.; Steenhuis, T.S.; Akhtar, M.S.; Walter, M.F. Phosphorus transport into subsurface drains by macropores after manure applications: Implications for best manure management practices. Soil Sci. 2001, 166, 896-909. [CrossRef]

14. Van Es, H.M.; Schindelbeck, R.R.; Jokela, W.E. Effect of manure application timing, crop, and soil type on phosphorus leaching. J. Environ. Qual. 2004, 33, 1070-1080. [PubMed]

15. Kleinman, P.J.; Sharpley, A.N.; Saporito, L.S.; Buda, A.R.; Bryant, R.B. Application of manure to no-till soils: Phosphorus losses by sub-surface and surface pathways. Nutr. Cycl. Agroecosys. 2009, 84, 215-227. [CrossRef]

16. Eastman, M.; Gollamudi, N.; Stampfli, N.; Madramootoo, C.A.; Sarangi, A. Comparative evaluation of phosphorus losses from subsurface and naturally drained agricultural fields in the Pike River watershed of Quebec, Canada. Agric. Water Manag. 2010, 97, 596-604. [CrossRef]

17. Tan, C.S.; Zhang, T.Q. Surface runoff and sub-surface drainage phosphorus losses under regular free drainage and controlled drainage with sub-irrigation systems in southern Ontario. Can. J. Soil Sci. 2011, 91, 349-359. [CrossRef]

18. Smith, D.R.; King, K.W.; Johnson, L.; Francesconi, W.; Richards, P.; Baker, D.; Sharpley, A.N. Surface runoff and tile drainage transport of phosphorus in the midwestern United States. J. Environ. Qual. 2015, 44, 495-502. [CrossRef]

19. King, K.W.; Williams, M.R.; Macrae, M.L.; Fausey, N.R.; Frankenberger, J.; Smith, D.R.; Kleinman, P.J.A.; Brown, L.C. Phosphorus transport in agricultural subsurface drainage: A review. J. Environ. Qual. 2015, 44, 467-485. [CrossRef]

20. King, K.W.; Williams, M.R.; Fausey, N.R. Contributions of systematic tile drainage to watershed-scale phosphorus transport. J. Environ. Qual. 2014, 44, 486-494. [CrossRef]

21. Madison, A.M.; Ruark, M.D.; Stuntebeck, T.D.; Komiskey, M.J.; Good, L.W.; Drummey, N.; Cooley, E.T. Characterizing phosphorus dynamics in tile-drained agricultural fields of eastern Wisconsin. J. Hydrol. 2014, 519, 892-901. [CrossRef]

22. Culley, J.L.B.; Bolton, E.F. Suspended solids and phosphorus loads from a clay soil: II. Watershed study. J. Environ. Qual. 1983, 12, 498-503. [CrossRef]

23. Macrae, M.L.; English, M.C.; Schiff, S.L.; Stone, M. Intra-annual variability in the contribution of tile drains to basin discharge and phosphorus export in a first-order agricultural catchment. Agric. Water Manag. 2007, 92, 171-182. [CrossRef]

24. King, K.W.; Fausey, N.R.; Williams, M.R. Effect of subsurface drainage on streamflow in an agricultural headwater watershed. J. Hydrol. 2014, 519, 438-445. [CrossRef]

25. Trevail, T.D. Soil Survey of Clinton County, New York; USDA-NRCS: Washington, DC, USA, 2006; pp. 104-106, 376-377.

26. American Public Health Association. Phosphorus: 4500-P. In Standard Methods for the Examination of Waste and Wastewaters, 17th ed.; Clesceri, L.S., Greenberg, A.E., Trussell, R.R., Eds.; Port City Press: Baltimore, MD, USA, 1989; pp. 166-181.

27. Howard, A.; (University of Vermont, Burlington, VT, USA). Personal communication, 2015.

28. Dolezal, F.; Kulhavy, Z.; Soukup, M.; Kodesova, R. Hydrology of tile drainage runoff. Phys. Chem. Earth 2001, 26, 623-627. [CrossRef] 
29. Needelman, B.A.; Gburek, W.J.; Petersen, G.W.; Sharpley, A.N.; Kleinman, P.J.A. Surface runoff along two agricultural hillslopes with contrasting soils. Soil Sci. Soc. Am. J. 2004, 68, 914-923. [CrossRef]

30. Kirkby, M. Hillslope runoff processes and models. J. Hydrol. 1988, 100, 315-339. [CrossRef]

31. Karl, T.R.; Knight, R.W. Secular trends of precipitation amount, frequency, and intensity in the United States. Bull. Am. Meteorol. Soc. 1998, 79, 231-241. [CrossRef]

32. Tan, C.S.; Drury, C.F.; Reynolds, W.D.; Gaynor, J.D.; Zhang, T.Q.; Ng, H.Y.F. Effect of long-term conventional tillage and no-tillage systems on soil and water quality at the field scale. Water Sci. Technol. 2002, 46, 183-190. [CrossRef]

33. Jamieson, A.; Madramootoo, C.A.; Enright, P. Phosphorus losses in surface and subsurface runoff from a snowmelt event on an agricultural field in Quebec. Can. Biosyst. Eng. 2003, 45, 1-7.

34. Rodzik, J.; Furtak, T.; Zglobicki., W. The impact of snowmelt and heavy rainfall runoff on erosion rates in a gully system, Lublin Upland, Poland. Earth Surf. Process. Landforms. 2009, 34, 1938-1950. [CrossRef]

35. Heckrath, G.; Brooks, P.C.; Poulton, P.R.; Goulding, K.W.T. Phosphorus leaching from soils containing different phosphorus concentrations in the Broadbalk experiment. J. Environ. Qual. 1995, 24, 904-910. [CrossRef]

36. Pote, D.H.; Daniel, T.C.; Sharpley, A.N.; Moore, P.A., Jr.; Edwards, D.R.; Nichols, D.J. Relating extractable soil phosphorus to phosphorus in runoff. J. Environ. Qual. 1996, 60, 855-859.

37. McDowell, R.W.; Sharpley, A.N. Approximating phosphorus release from soils to surface runoff and subsurface drainage. J. Environ. Qual. 2001, 30, 508-520. [CrossRef] [PubMed]

38. Maguire, R.O.; Sims, J.T. Soil testing to predict phosphorus leaching. J. Environ. Qual. 2002, 31, 1601-1609. [CrossRef] [PubMed]

39. Vadas, P.A.; Kleinman, P.J.A.; Sharpley, A.N.; Turner, B.L. Relating soil phosphorus to dissolved phosphorus in runoff. J. Environ. Qual. 2005, 34, 572-580. [CrossRef]

40. Kleinman, P.J.A.; Srinivasan, M.S.; Dell, C.J.; Schmidt, J.P.; Sharpley, A.N.; Bryant, R.B. Role of rainfall intensity and hydrology in nutrient transport via surface runoff. J. Environ. Qual. 2006, 35, 1248-1259. [CrossRef]

41. Chapman, A.S.; Foster, I.D.L.; Lees, J.A.; Hodgkinson, R.A. Sediment delivery from agricultural land to rivers via subsurface drainage. Hydrol. Processes. 2005, 19, 2875-2897. [CrossRef]

42. Stuntebeck, T.D.; Komiskey, M.J.; Owens, D.W.; Hall, D.W. Methods of Data Collection, Sample Processing, and Data Analysis for Edge-Of-Field, Streamgaging, Subsurface-Tile, and Meteorological Stations at Discovery Farms and Pioneer Farm in Wisconsin, 2001-7: U.S. Geological Survey Open-File Report 2008-1015. 2008. Available online: https://pubs.usgs.gov/of/2008/1015/pdf/ofr2008-1015.pdf (accessed on 22 January 2020).

43. Sharpley, A.N.; Kleinman, P.J.A.; Heathwaite, A.L.; Gburek, W.J.; Folmar, G.J.; Schmidt, J.P. Phosphorus loss from an agricultural watershed as a function of storm size. J. Environ. Qual. 2008, 37, 362-368. [CrossRef]

44. Correll, D.L. The Role of Phosphorus in the Eutrophication of Receiving Waters: A Review. J. Environ. Qual. 1998, 27, 261-266. [CrossRef]

45. Sharpley, A.N.; Jarvie, H.P.; Buda, A.; May, L.; Spears, B.; Kleinman, P.J.A. Phosphorus legacy: Overcoming the effects of past management practices to mitigate future water quality impairment. J. Environ. Qual. 2013, 42, 1308-1326. [CrossRef]

46. Sharpley, A.N.; Withers, P.J.A. The environmentally-sound management of agricultural phosphorus. Fert. Res. 1994, 39, 133-146. [CrossRef]

47. Gentry, L.E.; David, M.B.; Royer, T.V.; Mitchell, C.A.; Starks, K.M. Phosphorus transport pathways to streams in tile-drained agricultural watersheds. J. Environ. Qual. 2007, 36, 408-415. [CrossRef]

48. Vadas, P.A.; Good, L.W.; Jokela, W.E.; Karthikeyan, K.G.; Arriaga, F.J.; Stock, M. Quantifying the impact of seasonal and short-term manure application decisions on phosphorus loss in surface runoff. J. Environ. Qual. 2017, 46, 1395-1402. [CrossRef] [PubMed]

49. Easton, Z.M.; Kleinman, P.J.A.; Buda, A.R.; Goering, D.; Emberston, N.; Reed, S.; Drohan, P.J.; Walter, M.T.; Guinan, P.; Lory, J.A.; et al. Short-term forecasting tools for agricultural nutrient management. J. Environ. Qual. 2017, 46, 1257-1269. [CrossRef] [PubMed]

50. Dahlke, H.E.; Easton, Z.M.; Fuka, D.R.; Walter, M.T.; Steenhuis, T.S. Real-time forecast of hydrologically sensitive areas in the salmon creek watershed, New York state, using an online prediction tool. Water 2013, 5, 917-944. [CrossRef] 
51. Ketterings, Q.M.; Cela, S.; Collick, A.S.; Crittenden, S.J.; Czymmek, K.J. Restructuring the P index to better address P management in New York. J. Environ. Qual. 2017, 46, 1372-1379. [CrossRef] [PubMed]

52. Williams, M.R.; King, K.W.; LaBarge, G.A.; Confesor, R.B.; Fausey, N.R. Edge-of-field evaluation of the Ohio phosphorus risk index. J. Environ. Qual. 2016, 46, 1306-1313. [CrossRef]

(C) 2020 by the authors. Licensee MDPI, Basel, Switzerland. This article is an open access article distributed under the terms and conditions of the Creative Commons Attribution (CC BY) license (http://creativecommons.org/licenses/by/4.0/). 